\title{
Vascular Cell Kinetics in Response to Intimal Injury ex vivo
}

\author{
Nina-Maria Tigerstedt Hanna Savolainen-Peltonen Satu Lehti Pekka Hayry \\ Transplantation Laboratory, University of Helsinki and Helsinki University Central Hospital, Helsinki, Finland
}

\section{Key Words}

Aortic explant · Neointimal formation · Stem cell •

Restenosis $\cdot$ Smooth muscle cell

\begin{abstract}
Background: Recent studies indicate that the smooth muscle-like cells contributing to neointimal hyperplasia after vascular injury derive from circulating precursor cells. Here, we define the time course of precursor cell influx, the roles of separate vascular layers, and the relative role of migration versus proliferation to intimal hyperplasia. Methods and Results: After rat aortic denudation injury the neointimal cell number increased several 100 -fold between days 4 and 28 , preceded by a 5 -fold increase in the number of adventitial cells and a 4-fold increase in the number of adventitial microvessels. The influx, migration, and maturation of neointimal cells were quantitated by culturing whole vessel explants at different time points after injury. Explant outgrowth increased 14-fold, and cell migration 3.5-fold on days 2-14 after injury. Cell proliferation increased less than 2 -fold. The frequency of precursors to outgrowing cells, determined using limiting dilution analysis, increased 8-fold between days 2 and 4 after injury. Many outgrowing cells displayed characteristics of undifferentiated cells. Conclusions: Adventitial activation precedes development of the neointima, and precursor cell influx occurs on days 2-14 after injury. Cell migration, more than proliferation, contrib-
\end{abstract}

utes to fibrointimal dysplasia. These findings underline the importance of early therapeutic intervention with antimigratory compounds to prevent neointimal hyperplasia.

Copyright $\odot 2009$ S. Karger AG, Basel

\section{Introduction}

Characteristic of the response to injury following percutaneous transluminal coronary angioplasty [1] is the accumulation of smooth muscle-like cells at the inner side of the injured artery, their proliferation, migration, and synthesis of extracellular matrix, which results in the formation of a neointima, vascular remodeling, and restenosis [2].

Neointimal smooth muscle cells (SMC) after vascular injury may not originate from media, as previously believed, but represent a progeny of circulating precursors. In allografts, cells migrating to the vascular intima during chronic vascular rejection in mice, rats and humans derive from the recipient, not from the donor $[3,4]$. Circulating progenitor cells [5], probably of recent bone marrow origin $[6,7]$, give rise to the major part of the neointima in mouse and rat models of restenosis, allograft arteriosclerosis, and atherosclerosis, although contradictory evidence regarding the bone marrow origin of the cells also exists [8-11].

\section{KARGER}

Fax +4161306 1234

E-Mail karger@karger.ch

www.karger.com
(C) 2009 S. Karger AG, Basel

1018-1172/10/0471-0035\$26.00/0

Accessible online at:

www.karger.com/jvr
Dr. Nina-Maria Tigerstedt

Transplantation Laboratory, University of Helsinki

Haartmaninkatu 3, PO Box 21

FIN-00014 Helsinki (Finland)

Tel. +358 9 1911, Fax +358 9241 1227, E-Mail nina-maria.tigerstedt@helsinki.fi 
Previously the adventitia has been viewed as a passive supportive vascular layer consisting mostly of fibroblasts. In recent studies, however, it has emerged as a vascular layer actively contributing to neointimal hyperplasia, possibly as a site of entrance, or reserve, for circulating neointimal progenitor cells [12-15].

The aim of this study was to determine the time window of precursor cell influx into the vascular wall, the contribution of the separate vascular layers as well as the relative role of migration versus proliferation in the generation of the neointima.

\section{Materials and Methods}

\section{Aortic Denudation Injury}

Thoracic aortic denudations were performed on male Wistar rats (250-300 g, n = 3-5 per group, Harlan, Horst, The Netherlands) as described $[16,17]$. The rats were anesthetized with 240 $\mathrm{mg} / \mathrm{kg}$ i.p. chloral hydrate, and buprenorphine (Temgesic, Reckitt Coleman, Hull, UK) was given for postoperative pain relief. All animals received humane care in compliance with the Guide for the Care and Use of Laboratory Animals prepared and formulated by the National Institutes of Health (NIH publication No. 86-23, revised 1996). Nonoperated rats were used as controls, since we previously tested and found no difference in results from nonoperated versus sham-operated rats (unpubl. observation).

\section{Vessel Histology and Immunohistochemistry}

The animals were sacrificed at $15 \mathrm{~min}, 1,2,3,4,7,14,21,28$ days, and 2 and 3 months after injury. Half of each aorta was used for histology, and the other half for explant cultures. Histological specimens were processed as described [16]. Numbers of nuclei and microvenules were quantitated microscopically from paraffin cross sections stained with Mayer's hematoxylin-eosin, using $400 \times$ magnification. In addition, the histological specimens were stained with a polyclonal antibody for von Willebrand factor (rabbit, 1:200, A0082, Dako, Glostrup, Denmark), and monoclonal antibodies for smooth muscle $\alpha$-actin (SMA, 1:200, A2547, Sigma, St. Louis, Mo., USA), vimentin (1:100, M0725, Dako), MECA-79 (1:50, 553863, Becton Dickinson Biosciences Pharmingen, San Diego, Calif., USA), HECA-452 (1:50, 550407, Becton Dickinson Biosciences Pharmingen), Flk-1 (1:100, sc-6251, Santa Cruz Biotechnology, Santa Cruz, Calif., USA), and CD34 (1:100, sc-52478, Santa Cruz Biotechnology) using a commercial avidin-peroxidase ABC method (Vectastain Elite ABC Kit, Vector Laboratories, Burlingame, Calif., USA), according to the manufacturers' instructions. The primary antibody was incubated at room temperature for $60 \mathrm{~min}$.

Controls for antibody staining included replacing the primary antibody with irrelevant antibody (M0744, Dako) and omitting the primary antibody. Control stainings showed no immunoreactivity. The intensity of the staining was scored blindly as percent of stained cells of all cells.

\section{Explant Culture}

The culture medium consisted of Dulbecco's modified Eagle's medium (Gibco, Paisley, UK) supplemented with $10 \%$ fetal bovine serum (FBS, Gibco), $100 \mathrm{IU} / \mathrm{ml}$ penicillin, $100 \mu \mathrm{g} / \mathrm{ml}$ streptomycin and $2 \mathrm{mmol} / \mathrm{l} \mathrm{L}$-glutamine.

The aortas, including all layers of the vessel, were opened longitudinally and explants measuring $1 \times 1 \mathrm{~mm}$ were prepared using a McIlwain tissue chopper (Mickle Laboratory Engineering, Guildford, UK). The explants were placed individually into the wells of a flat-bottomed 96-well plate (Nunc, Roskilde, Denmark) with $20 \mu \mathrm{l}$ basal medium to keep them damp. Seventy-two wells of the plate were used for the cultures, whilst the border wells were filled (to maintain humidity) only with distilled water. The plates were placed in a $+37^{\circ} \mathrm{C}$ incubator with an atmosphere of $95 \%$ air and $5 \% \mathrm{CO}_{2}$ for $2 \mathrm{~h}$ to allow adherence to the tissue culture plastic. Two hundred microliters of the test medium were then added to each well.

Each well was observed after $24 \mathrm{~h}$ of culture and counted as positive for 'sprouting' if one or more cells had grown out of the explants. The distance that the leading edge of migrating cells in each well had travelled from the explant was measured using a calibrated graticule (Olympus, Tokyo, Japan).

To quantitate proliferating cells, the explants were pulsed with tritiated thymidine $\left(25 \mathrm{Ci} / \mathrm{mmol}\left[{ }^{3} \mathrm{H}\right] \mathrm{TdR}\right.$, Amersham International, Amersham, UK) on day 0. Upon termination of culture, the outgrowing cells were detached from the wells with trypsin and the explants were digested with pepsin (Merck, Darmstadt, Germany) at $+37^{\circ} \mathrm{C}$ for $50 \mathrm{~min}$. Then, the content of each well was harvested with a Dynatech Harvester (Dynatech Labs, Billingshurst, UK) and mixed with OptiScint Hisafe (LKB-Wallac, Turku, Finland). Radioactivity was measured with a Rackbeta liquid scintillation counter (LKB-Wallac).

\section{Limiting Dilution Assay}

Limiting dilution analysis of culture-initiating cells is a quantitative method commonly used to obtain an estimate of progenitor cell activity [18]. Instead of conventionally setting up a limiting dilution assay using different cell concentrations we varied the explant size, and calculated the number of sprouting cell precursors based on an approximation of explant cell numbers. Samples of aortic explants from both injured and uninjured aortas measuring $1 \times 1,0.5 \times 0.5,0.3 \times 0.3$, and $0.1 \times 0.1 \mathrm{~mm}$ were cultured as described above. Cell outgrowth was scored on day 1 as either positive or negative, and estimates of precursor frequencies were calculated with the L-Calc Software for Limiting Dilution Analysis based on the Poisson model.

\section{Immunohistochemistry of Sprouts}

Immunohistochemistry was used to identify cells growing from aortic explants. Tissue culture-treated glass slides (Becton Dickinson, Franklin Lakes, N.J., USA) were coated with collagen (20 $\mu \mathrm{g} / \mathrm{ml}$ rat tail collagen, type 1; Upstate Biotechnology, Lake Placid, N.Y., USA) at $+4^{\circ} \mathrm{C}$ overnight, and aortic explants were placed onto the slides. Fifty microliters of culture medium were added to keep the explants damp, and the slides were incubated in a $+37^{\circ} \mathrm{C}$ incubator for $4 \mathrm{~h}$, as above, to allow adherence to the slides. Thereafter, $250 \mu \mathrm{l}$ of culture medium was added to each well and the explants were cultured for 7 days. On day 7, the explants and cells were fixed with $3 \%$ paraformaldehyde solution for 


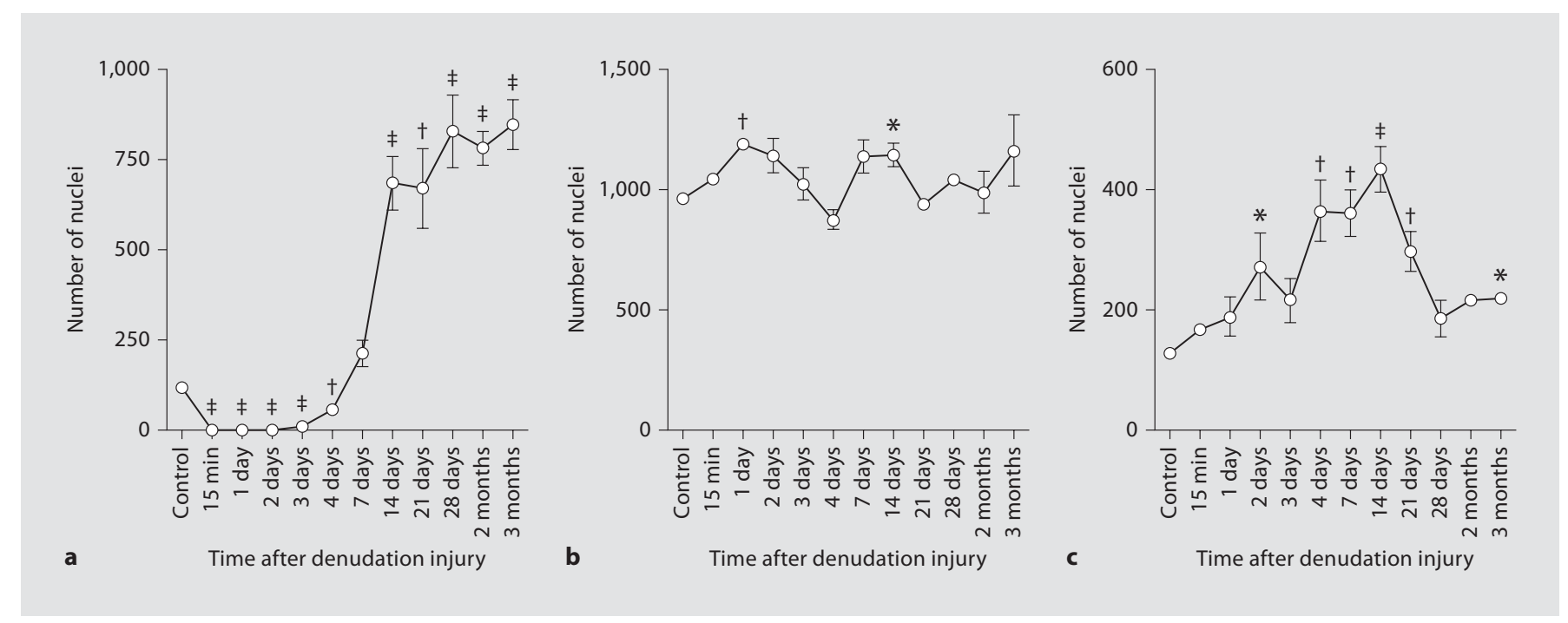

Fig. 1. The number of nuclei in intima (a), media (b), and adventitia (c) at different time points after ballooning injury, quantitated from paraffin cross sections. The data are expressed as mean $\pm \operatorname{SEM}(n=3) .{ }^{*} \mathrm{p}<0.5$; ${ }^{\dagger} \mathrm{p}<0.01 ;{ }^{\ddagger} \mathrm{p}<0.001$ compared to control.

$15 \mathrm{~min}$, after which the slides were kept damp with sterile PBS at $+4^{\circ} \mathrm{C}$ until stained.

The cells were stained for single or double stainings as described above with a polyclonal antibody for CD11b $(1: 100$, sc6614, Santa Cruz Biotechnology) and monoclonal antibodies for mononuclear phagocytes (1:200, 22451D, Becton Dickinson Biosciences Pharmingen), and leukocyte common antigen (LCA, 1:50, M0701, Dako). Antibodies for von Willebrand factor (1:100, Dako), SMA (1:200, Sigma), vimentin (1:100, Dako), Flk-1 (1:100, Santa Cruz Biotechnology), and CD34 (1:100, Santa Cruz Biotechnology) are described above.

\section{Statistical Analysis}

Data are presented as mean \pm SEM. Statistical evaluations were made with Student's unpaired t test. $\mathrm{p}<0.05$ were considered statistically significant.

\section{Results}

\section{Histological Changes in the Vessel Wall after}

Endothelial Denudation Injury

Histological changes in the rat thoracic aorta in vivo were evaluated at $15 \mathrm{~min}, 1,2,3,4,7,14,21,28$ days, and 2 and 3 months after injury (fig. 1). Denudation injury led to complete loss of endothelial cells in the luminal side of the internal elastic lamina. The first neointimal cells appeared on day 4 . The intima nuclei number increased between 4 and 28 days from $<50$ to 800 nuclei per vessel circumference $(p<0.001)$, after which a plateau was reached. The number of medial nuclei remained unchanged. Notably, the number of adventitial nuclei increased between days 2 and 14 from 200 to 450 nuclei per vessel circumference $(\mathrm{p}<0.001)$, clearly preceding neointima formation, after which it decreased to the predenudation level.

\section{Induction of Adventitial Microvessels after Vascular Injury}

As adventitial remodeling evidently preceded the rise in neointimal cell number, we presumed that intima cell precursors may find their way into the vessel lumen through adventitia. Therefore, we went to investigate the regulation of adventitial microvessels in this process as it is well known that other cells, such as lymphocytes, enter tissues through high endothelial venules (HEV) [19]. In the adventitia of resting thoracic aorta, prior to denudation, we identified around 10 microvenules per vessel circumference. After denudation, the number of vessels increased to 40 between days 7 and 21 ( $p<0.05$ compared to control), after which their number returned to the predenudation level (fig. 2a, b). The vessels did not express MECA-79 or HECA, typical markers of HEVs (not shown).

\section{Immunohistochemistry of the Vascular Wall after \\ Endothelial Denudation Injury in vivo}

To clarify the in vivo phenotypes of cells entering the vascular wall we stained aortas taken at 3, 4, 7, 14, 21 and 
Fig. 2. a The number of microvessels in the adventitia after denudation injury, quantitated from paraffin cross sections. The data are expressed as mean \pm SEM $(\mathrm{n}=3) .{ }^{*} \mathrm{p}<0.5$ compared to control. b Representative photomicrographs of rat aortas before and at different time points after endothelial injury. HE. $\times 400$. Insets $\times 800$. The arrows indicate adventitial microvessels.

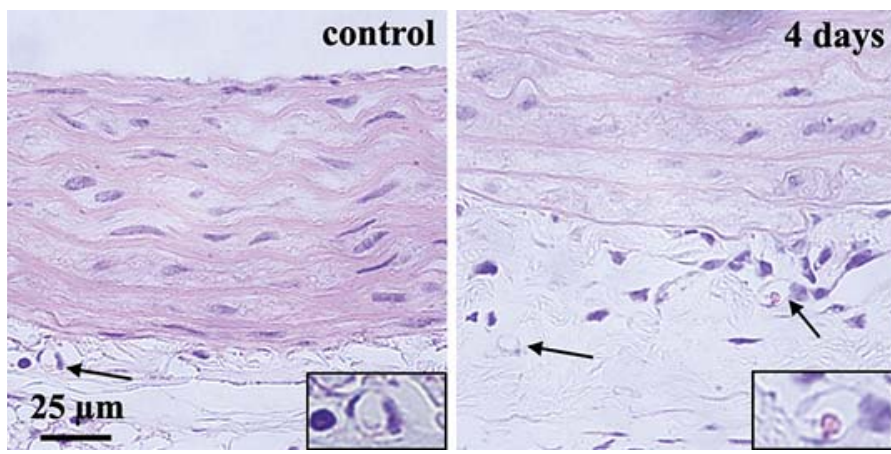

28 days after injury for the endothelial cell-specific antigen von Willebrand factor, the SMC-specific $\alpha$-actin antigen (SMA), the cytoskeletal protein vimentin, and the stem cell markers Flk-1 and CD34. Representative photomicrographs are presented in figure 3.

Von Willebrand factor was found exclusively in the endothelial layer of normal nondenuded aortas as well as the lumen of adventitial microvessels. Of the first neointimal cells appearing on day 4 after injury, almost half stained positive for the von Willebrand factor. Reendothelialization of the neointima occurred between 7 and 28 days after injury, and at the end of the follow-up, most of the luminal side of the neointima expressed von Willebrand factor.


In normal nondenuded arteries, SMA was expressed predominantly in the medial layer and the staining intensity in the media remained strong throughout the follow-up. The first neointimal cells, appearing on day 4 after injury, did not express SMA, but a few positive cells were observed on day 7. On day 14, the whole neointima stained faintly positive. Thereafter, the staining intensity increased, and on days 21 and 28 after injury both the neointima and media showed equal, intense staining throughout the layers.

The cytoskeletal protein vimentin, usually found in SMC and fibroblasts, was expressed in all layers of the nondenuded vascular wall. At 3-4 days after injury, vimentin was mainly localized in the adventitia. Thereaf- 


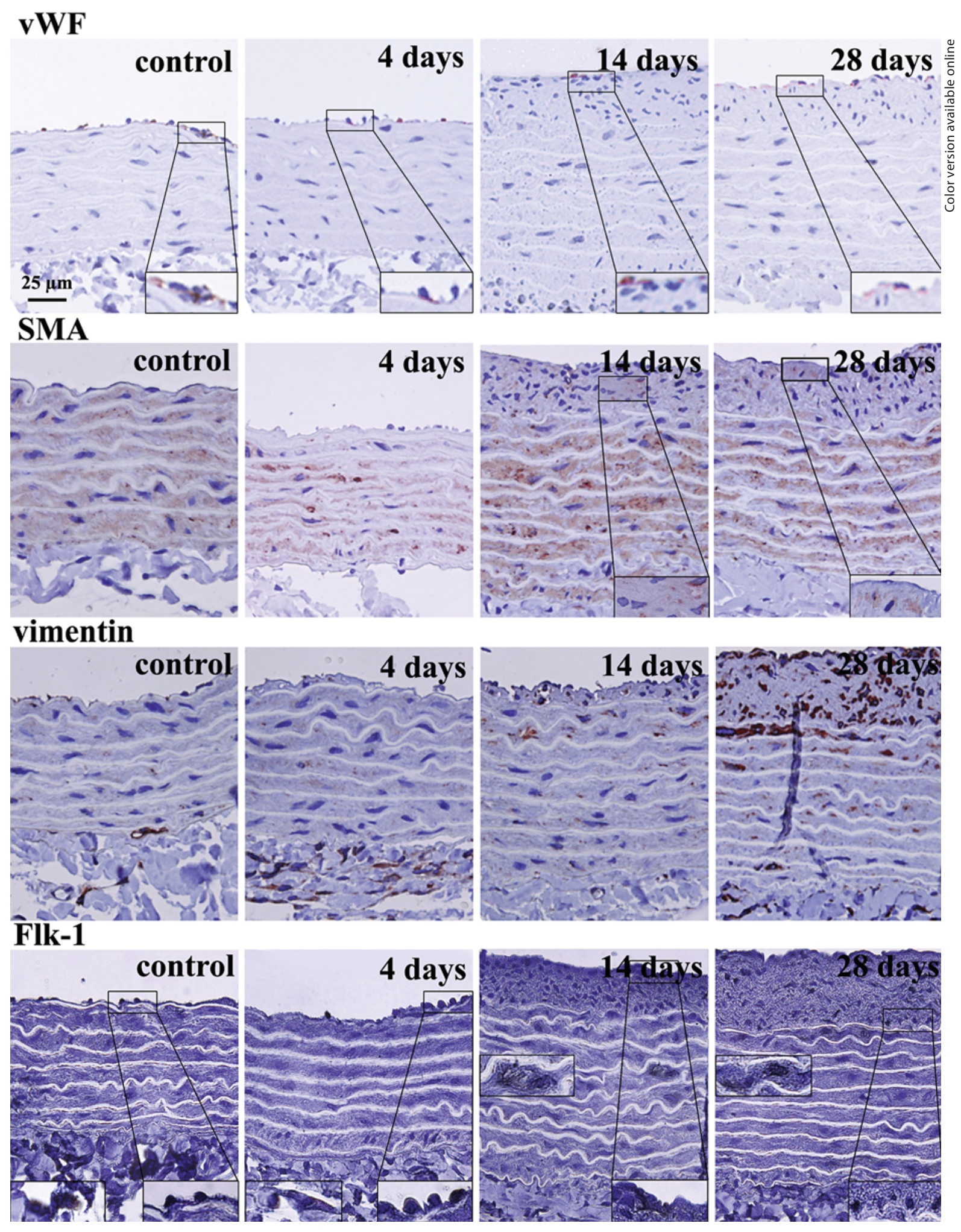

Fig. 3. Representative photomicrographs of rat aortas before and at different time points after endothelial injury. The specimens were stained with specific antibodies for von Willebrand factor (vWF, red, Dako, 1:200), SMC $\alpha$-actin (SMA, red, Sigma, 1:5,000), vimentin (red, Dako, 1:100), and Flk-1 (black, Santa Cruz Biotechnology, 1:100). Hematoxylin counterstain. $\times 400$. Insets $\times 800$. 


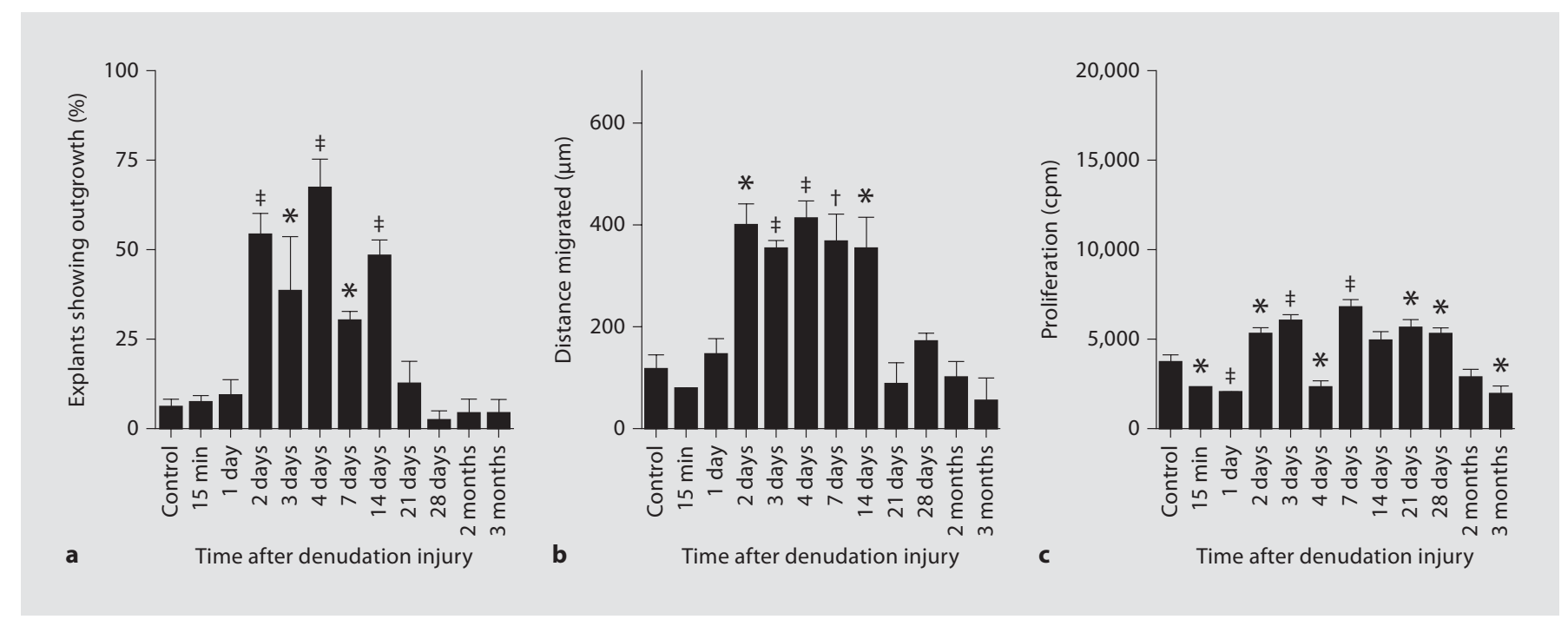

Fig. 4. The effect of denudation injury on outgrowth (a), migration (b), and proliferation (c) in whole vessel explants at 15 min, 1, 2, 3, 4, 7, 14, 21, 28 days, and 2 and 3 months after injury. Outgrowth was measured as the percentage of explants showing outgrowth, migration as the distance the leading edge of the sprouting cells had traveled from the explant, and replication as $\left[{ }^{3} \mathrm{H}\right] \mathrm{TdR}$ incorporation. The data are expressed as mean \pm SEM of three separate experiments. ${ }^{*} \mathrm{p}<0.5 ;{ }^{\dagger} \mathrm{p}<0.01 ;{ }^{\ddagger} \mathrm{p}<0.001$ compared to control.

ter, the intensity of adventitial staining declined, and from 21 days on, vimentin expression shifted predominantly in the neointima.

In nondenuded arteries, the vascular progenitor cell marker Flk-1 [20] was expressed in the adventitia and occasionally in intimal cells. Early after denudation injury, Flk-1 was localized to the first cells appearing in the neointima and to the adventitia. At day 14 after injury and thereafter, Flk-1 was expressed in all layers of the vascular wall, with the highest staining intensity in neointima. We were unable to show CD34 protein in any of the samples.

\section{Effects of Denudation Injury on Cell Outgrowth from Aortic Explants}

The evaluation of histological changes presented thus far led us to the conclusion that there is a high turnover of cells possibly from extravascular sites to the adventitia and from the adventitia into the intimal layer. To be able (1) to dissect the kinetics of influxing cells in the vascular wall, (2) to follow the maturation of these cells ex vivo, and (3) to determine the time window of cell influx we used aortic explants. Explants $(1 \times 1 \mathrm{~mm})$ were taken at the same time points after injury as those used for histology and were individually placed in wells of a 96-well plate and cultured ex vivo for $48 \mathrm{~h}$. The percentage of wells showing outgrowth, or 'sprouting', increased from the predenudation level of $5.1 \pm 2.3 \%$ to $30-65 \%$ in explants obtained 2-14 days postdenudation, after which the sprouting frequency declined. The highest frequency was found in explants obtained on day 4 after injury $(67.3$ $\pm 5.0 \%, \mathrm{p}<0.0001$ compared to control) (fig. $4 \mathrm{a}$ ).

The distance that the cells migrated from the explant was $116 \pm 31 \mu \mathrm{m}$ in explants from uninjured rats and it increased significantly in explants obtained from injured vessels at 2-14 days after denudation. Migration peaked on day $4(413 \pm 34 \mu \mathrm{m}, \mathrm{p}=0.0004$ compared to control), and returned to the control level after day 14 after injury (fig. 4b).

Cell replication was measured by $\left[{ }^{3} \mathrm{H}\right] \mathrm{TdR}$ uptake. All sprouted cells as well as the explant itself were included in the measurements. DNA synthesis peaked on day 7 after denudation injury with $6,771 \pm 452 \mathrm{cpm}$ as compared to control $(3,700 \pm 466 \mathrm{cpm}, \mathrm{p}<0.0001)$. Thereafter, the response declined and returned to the control level by 28 days after injury (fig. 4c).

\section{Quantitation of Progenitor Cell Influx ex vivo}

Sprouts most likely represent the putative precursor cells in the vascular wall and, therefore, to quantify the frequency of precursors to 'sprouts' at different time points after injury, we cultured explants from denuded 
and nondenuded control aortas under limiting dilution conditions. The frequency of progenitors of sprouting cells in normal rat aorta, according to the Poisson distribution equation, was 18.1 cells $/ \mathrm{cm}^{2}$ (SE range 14.1-23.3 cells $/ \mathrm{cm}^{2}$ ). It increased to 95.2 cells $/ \mathrm{cm}^{2}$ (SE range 84.7106.4 cells $/ \mathrm{cm}^{2}$ ) at 2 days, and peaked at 4 days after denudation injury with 151.5 cells $/ \mathrm{cm}^{2}$ (SE range 133.3172.4 cells $/ \mathrm{cm}^{2}$ ). Thereafter, the progenitor cell frequency declined and was $12.1 \mathrm{cells} / \mathrm{cm}^{2}$ (SE range $8.5-17.3$ cell/ $\mathrm{cm}^{2}$ ) at 21 days after injury (fig. 5).

\section{Identification of Outgrowing Cells ex vivo}

The explant assay allows us to complete the injury process initiated in vivo in an ex vivo environment and, therefore, to follow more closely the fate and maturation of influxing cells. The same antibodies used in vivo were used ex vivo to identify the outgrowing cells. Of the outgrowing cells, $77.0 \pm 7.4 \%$ expressed SMA, $59.7 \pm 7.4 \%$ expressed vimentin, and $50.8 \pm 7.2 \%$ the von Willebrand factor. The percentage of Flk-1-positive cells was as high as $41.5 \pm 3.6 \%$, and that of CD34-positive cells was 14.3 $\pm 2.9 \%$ (fig. 6 ). Only $0.05 \pm 0.015 \%$ of the cells were positive for the mononuclear phagocyte antigen and 2.6 $\pm 2.5 \%$ for the leukocyte antigen (LCA; not shown).

As the percentages of cells expressing the different markers overlapped, double immunohistochemistry was performed. Most SMA-positive cells, $80.7 \pm 2.5 \%$, also expressed vimentin and $47.8 \pm 11.9 \%$ the von Willebrand factor. Of the vimentin-positive cells, $56.8 \pm 8.1 \%$ expressed SMA and $14.9 \pm 3.6 \%$ the von Willebrand factor. Of the von Willebrand factor-positive cells, $59.5 \pm 14.1 \%$ also expressed vimentin and $49.3 \pm 6.5 \%$ SMA. Of the few LCA-positive cells seen, $87.5 \pm 5.5 \%$ expressed SMA, $42.7 \pm 9.0 \%$ the von Willebrand factor, and $82.6 \pm 4.9 \%$ vimentin (fig. 7).

\section{Discussion}

We may deduce the following from these results. During neointimal formation, the influx of precursor cells occurs very shortly after endothelial removal, mostly on days 2-4. Activation of the adventitia suggests that the influxed cells are temporarily parked in the vascular adventitia on days $2-14$, and they migrate into the intima on days 7-28. Along with time the cells gradually begin to express vascular SMC markers and lose markers of less differentiated cells. Finally, the migration ceases when endothelial lining is reestablished on the luminal side.

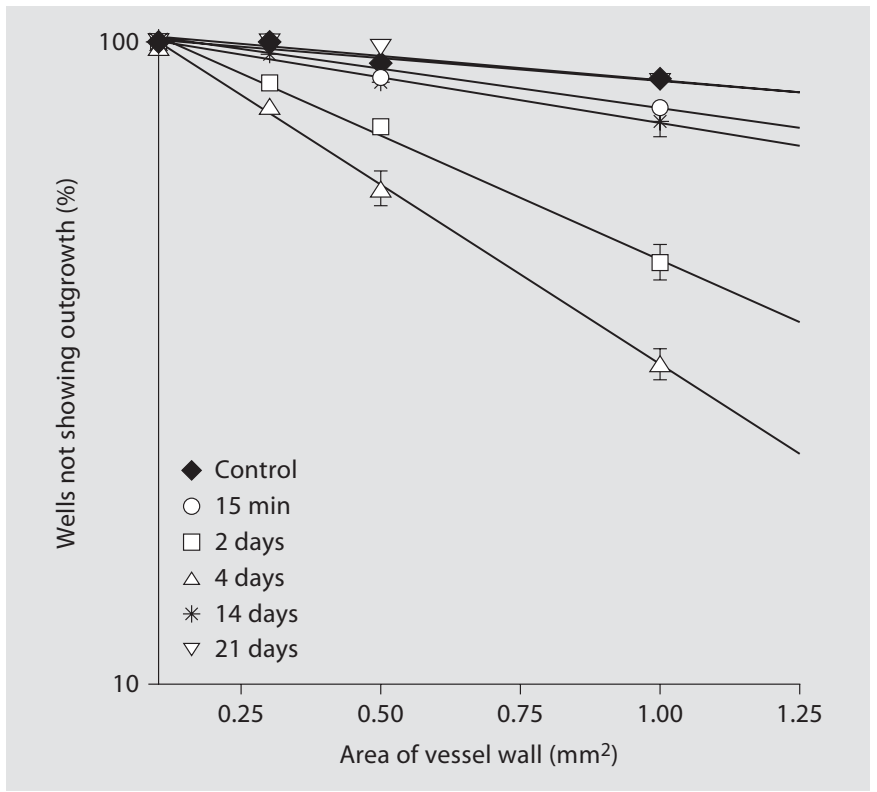

Fig. 5. Limiting dilution assay performed at different time points after denudation injury. The logarithmic y-axis represents the percentage of wells not showing outgrowth and the linear $\mathrm{x}$-axis the area of the vessel wall.

Adventitial SMA-negative cells have been reported to contribute to arterial repair by migrating to the neointima and maturing into SMA-positive myofibroblasts [13]. In mice carotid allografts the first cells of host origin are localized to the adventitia at 7 days after transplantation, whereas they do not appear in the neointima or media until 1 week later [14]. A recent report indicates that vascular progenitors with the capability of differentiating into SMC participating in lesion formation are present in the adventitia [15]. Also, adventitial capillary formation, 'adventitial angiogenesis', has been shown to correlate with the growth of neointima [21]. In our earlier studies [12], BrdU-incorporating cells were first observed in the adventitia on days $2-4$, and only thereafter in the intima on days 4-14. However, the number of replicating cells in the intima, after continuous labeling of the rat from 0 to $72 \mathrm{~h}$, was less than $20 \%$, indicating that most of the cells in the intima had migrated rather than having been born by cell division after the surgery. Here, the in vivo histological analysis of the injury response showed that the number of cells and microvessels in the adventitia increased significantly between 2 and 14 days and that of intimal cells shortly thereafter. Adventitial remodeling and intimal hyperplasia in vivo were preceded by high outgrowth activity and a strong migratory response in 
Fig. 6. Representative photomicrographs of control (a), SMC $\alpha$-actin (Sigma, 1:200) (b), vimentin (Dako, 1:100) (c), von Willebrand factor (Dako, 1:100) (d), Flk-1 (Santa Cruz Biotechnology, 1:100) (e), and CD34 (Santa Cruz Biotechnology, 1:100) (f) immunostainings of cells growing out of aortic explants 2 days after intimal injury. Hematoxylin counterstain. $\times 200$ magnification (control $\times 100$, Flk-1 and CD34 $\times 1,000)$. The arrow in $\mathbf{a}$ indicates the aortic explant.
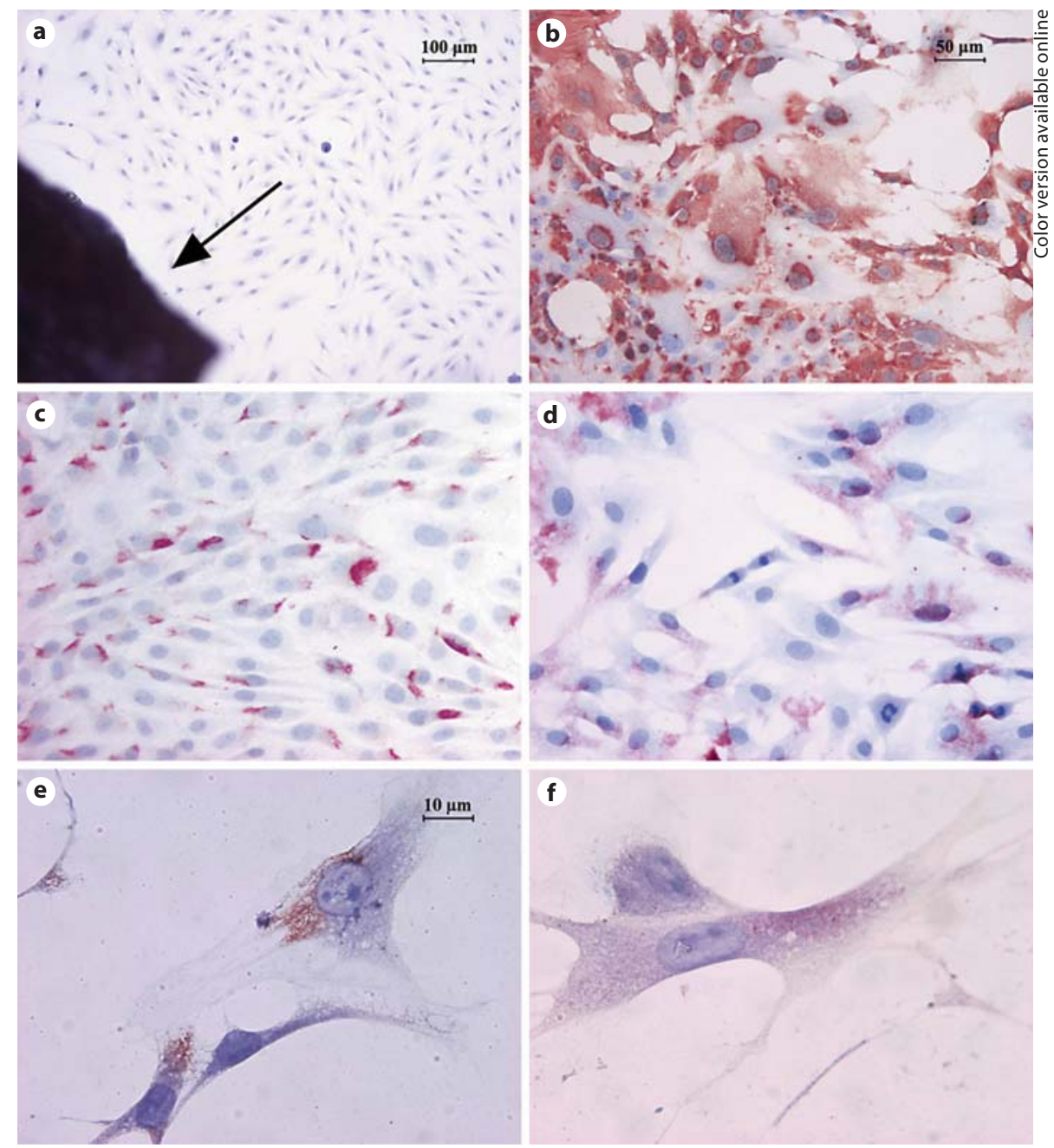

the explants ex vivo, peaking between 2 and 4 days after injury. Immunostainings of the in vivo specimens showed that vimentin and Flk-1 expression shifted from the adventitia to the neointima within 3-28 days after injury. We hypothesized that the adventitial microvessels would actually represent 'postcapillary HEV', the type of vessel responsible for the migration of inflammatory leukocytes into tissues [19]. However, our attempts to employ marker antibodies for HEV, mostly rat monoclonals, repeatedly failed to show that adventitial vessels would express HEV markers. Still, these results suggest that the adventitia might have an important role as a first station on the route of cell migration into the neointima in the development of neointimal hyperplasia.

As the maturation of sprouting cells from the explants faithfully resembles the maturation of these cells in vivo, we believe that the ex vivo model completes the process initiated in vivo. Most importantly, the cell influx from outside of the vascular wall may be compartmentalized by isolating vessel fragments at different time points, making it possible to determine the critical time window for their entry into the vessel wall, as well as the migration and replication of the progeny of the precursors at different time points after the injury. By developing the explant experiment one step further and setting it up under limiting dilution conditions, we were able to present an estimate for the frequency of precursors to sprouts in the arterial wall. The peak in precursor cell frequency was observed on days $2-4$, and it decreased to the control level on day 21 after injury. This finding suggests a very rapid mobilization and differentiation of these cells to and at the site of injury. Since the explant outgrowth and migration also peaked at the same time points, the precursors probably contribute to these processes. Interest- 
Fig. 7. Representative photomicrographs of the double immunostainings of cells growing out of aortic explants at 2 days after injury. A population of cells staining positive for SMA (red) only (a), and cells from the same slide staining positive for both SMA (red) and vimentin (black) (b). c Vimentin (red) and von Willebrand factor (black). d SMA (red) and von Willebrand factor (black). e SMA (red) and LCA (black). f Von Willebrand factor (red) and LCA (black). Hematoxylin counterstain. $\times 1,000$.
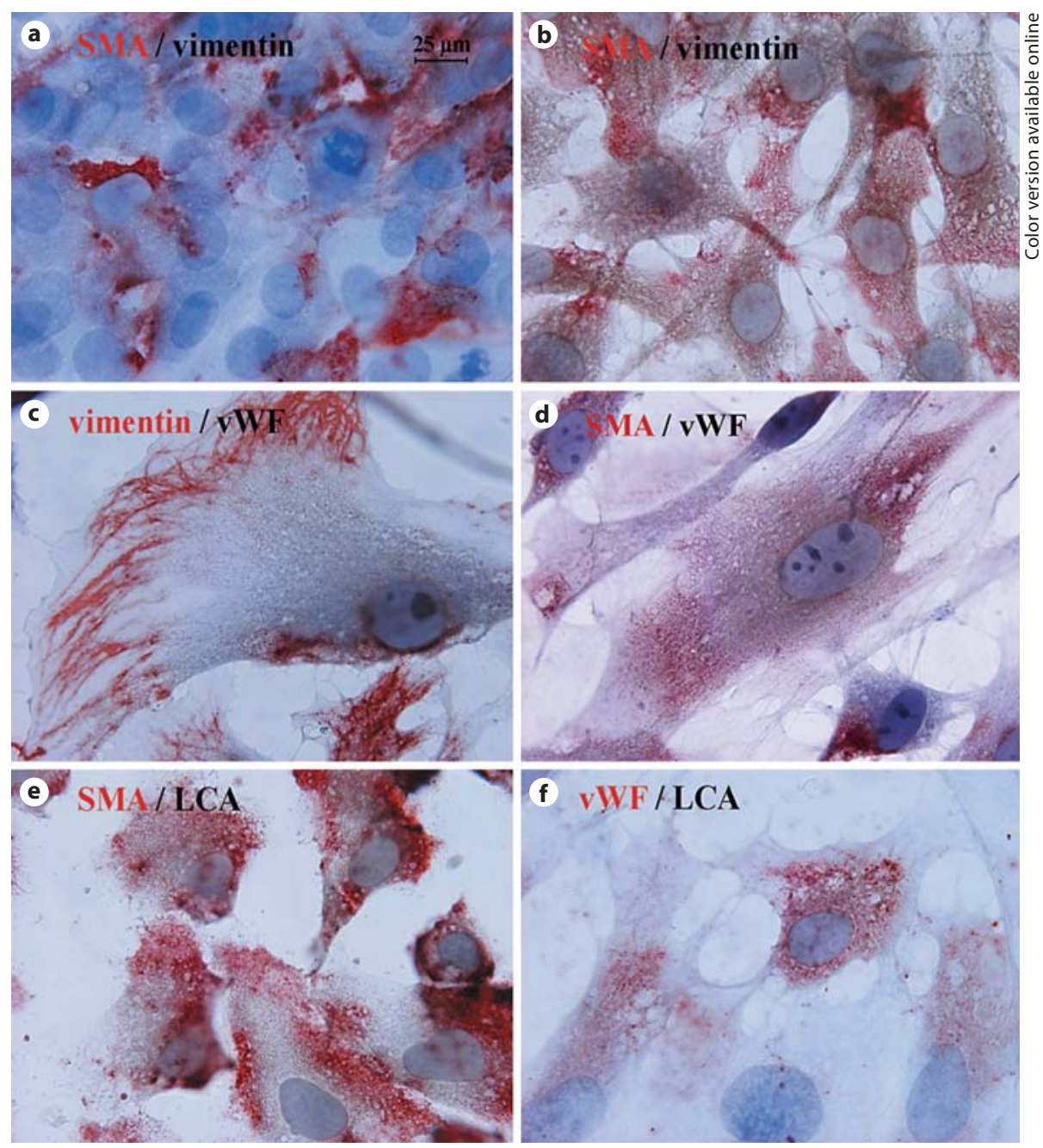

ingly, in our previous studies the application of vasculoprotective compounds for the first 14 days after injury only completely prevented intimal hyperplasia $[22,23]$, a phenomenon most likely explained by the crucial early time window of precursor cell influx we have defined here.

A remarkable number of the cells growing out of the explants showed overlapping expression for SMA and von Willebrand factor, SMA and vimentin, and for vimentin and von Willebrand factor. Occasional LCA-positive cells staining for SMA or von Willebrand factor were also seen, suggesting that these cells might be undifferentiated. Furthermore, a significant part of the cells expressed the precursor cell markers Flk-1 or CD34. This finding is also compatible with the stem cell theory.

Although both replication and migration seem to contribute to the intimal injury response, it has been proposed that the role of migration is more important than that of replication [24]. In this study, the peak in explant proliferation $\left(\left[{ }^{3} \mathrm{H}\right] \mathrm{TdR}\right.$ incorporation) was observed on day 7 after injury, most likely reflecting the peak in in vivo neointimal proliferation at that time [12]. However, while explant outgrowth increased 14-fold, replication only doubled, which suggests that explant outgrowth mainly reflects migration - possibly both from the nearby vessel wall and from extravascular tissues - and that migration is the major response to intimal injury.

These deductions are not flawless. Our attempts to use rats with GFP-chimeric bone marrow did not produce a sufficiently high level of chimerism in circulation to directly follow the movement of cells. Furthermore, rat models are challenging as the selection of stem cell markers suitable for the use in this species is very limited, at 
least compared to the mouse. On the other hand, the vessel size in the mouse is too small for explant preparation. Also, we failed to show any CD34 protein in the vessel samples. The amount of CD34-positive cells in the vessel samples might have been below the detection sensitivity of the immunohistological staining method used.

Nevertheless, our findings confirm the role of the adventitia as a vascular layer actively participating in vascular repair, and suggest that cell migration is the main response to vascular injury. Furthermore, our results indicate that precursor cell influx occurs already during the first days after injury and that the event is surpris- ingly short. This underlines the importance of early intervention with antimigratory compounds to prevent neointimal hyperplasia.

\section{Acknowledgments}

The study was supported by grants from the Academy of Finland, the Sigrid Juselius Foundation, University of Helsinki Hospital Research Funds, Finska Läkaresällskapet, Nylands Nation, Orion Pharma, the Paulo Foundation, the Paavo Nurmi Foundation, and Helsinki Biomedical Graduate School, Helsinki, Finland.

The authors wish to thank Eva Sutinen, RN and Eriika Wasenius, $\mathrm{RN}$ for excellent technical assistance.

\section{References}

1 Holmes D, Vliestsra R, Smith H, et al: Restenosis after percutaneous transluminal coronary angioplasty. Am J Cardiol 1984;53: $77 \mathrm{C}-81 \mathrm{C}$

-2 Ross R: Growth regulatory mechanisms and formation of the lesions of atherosclerosis. Ann NY Acad Sci 1995;748:1-4.

3 Hillebrands JL, Klatter FA, van den Hurk GM, Popa ER, Nieuwenhuis P, Rozing J: Origin of neointimal endothelium and alphaactin-positive smooth muscle cells in transplant arteriosclerosis. J Clin Invest 2001;107: 1411-1422.

-4 Grimm PC, Nickerson P, Jeffery J, et al: Neointimal and tubulointerstitial infiltration by recipient mesenchymal cells in chronic renal allograft rejection. N Engl J Med 2001;345: 93-97.

5 Saiura A, Sata M, Hirata Y, Nagai R, Makuuchi M: Circulating smooth muscle progenitor cells contribute to atherosclerosis. Nat Med 2001;7:382-383.

6 Sata M, Saiura A, Kunisato A, et al: Hematopoietic stem cells differentiate into vascular cells that participate in the pathogenesis of atherosclerosis. Nat Med 2002;8:403-409.

7 Han CI, Campbell GR, Campbell JH: Circulating bone marrow cells can contribute to neointimal formation. J Vasc Res 2001;38: 113-119.

-8 Li J, Han X, Jiang G, Zhong R, Williams GM, Pickering JG, Chow LH: Vascular smooth muscle cells of recipient origin mediate intimal expansion after aortic allotransplantation in mice. Am J Pathol 2001;158:19431947.
9 $\mathrm{Hu}$ Y, Davison F, Luedwig B, et al: Smooth muscle cells in transplant atherosclerotic lesions are originated from recipients, but not bone marrow progenitor cells. Circulation 2002;106:1834-1839.

10 Hu Y, Mayr M, Metzler B, Erdel M, Davison F, Xu Q: Both donor and recipient origins of smooth muscle cells in vein graft atherosclerotic lesions. Circ Res 2002;91:e13-e20.

11 Hillebrands JL, Klatter FA, van Dijk WD, Rozin J: The bone-marrow does not contribute substantially to host-derived endothelial cell replacement in transplant arteriosclerosis. Nat Med 2002;8:194-195.

12 Frosen J, Calderon-Ramirez L, Hayry P, Myllarniemi M: Quantitation of cell migration in a rat carotid artery balloon injury model. Indications for a perivascular origin of the neointimal cells. Cardiovasc Drugs Ther 2001; 15:437-444.

13 Shi Y, O’Brien JE, Fard A, Mannion JD, Wang D, Zalewski A: Adventitial myofibroblasts contribute to neointimal formation in injured porcine coronary arteries. Circulation 1996;94:1655-1664.

14 Matsumoto Y, Hof A, Baumlin Y, Muller M, Prescott M, Hof R: Dynamics of medial smooth muscle changes after carotid artery transplantation in transgenic mice expressing green fluorescent protein. Transplantation 2003;76:1569-1572.

$15 \mathrm{Hu}$ Y, Zhang Z, Torsney E, Afzal AR, Davison F, Metzler B, Xu Q: Abundant progenitor cells in the adventitia contribute to atherosclerosis of vein grafts in ApoE-deficient mice. J Clin Invest 2004;113:1258-1265.

- 16 Myllarniemi M, Calderon L, Lemstrom K, Buchdunger E, Hayry P: Inhibition of platelet-derived growth factor receptor tyrosine kinase inhibits vascular smooth muscle cell migration and proliferation. FASEB J 1997; 11:1119-1126.
17 Myllarniemi M, Rasilainen S, Lemstrom K, Hayry P: Enhanced intimal proliferation upon injury to pre-existing neointima and resistance of neointimal cells to cell death. Cardiovasc Pathol 1999;8:339-347.

18 Dozmorov I, Eisenbraun MD, Lefkovits I: Limiting dilution analysis: from frequencies to cellular interactions. Immunol Today 2000;21:15-18.

19 Renkonen R, Turunen JP, Rapola J, et al: Characterization of high endothelial-like properties of peritubular capillary endothelium during acute renal allograft rejection. Am J Pathol 1990;137:643-651

20 Yamashita J, Itoh H, Hirashima M, Ogawa M, Nishikawa S, Yurugi T, Naito M, Nakao K, Nishikawa S: Flk1-positive cells derived from embryonic stem cells serve as vascular progenitors. Nature 2000;408:92-96.

21 Pels K, Labinaz M, Hoffert C, et al: Adventitial angiogenesis early after coronary angioplasty: correlation with arterial remodeling. Arterioscler Thromb Vasc Biol 1999;19:229238

22 Vamvakopoulos JE, Petrov L, Aavik S, et al: Synergistic suppression of rat neointimal hyperplasia by rapamycin and imatinib mesylate: implications for the prevention of accelerated arteriosclerosis. J Vasc Res 2006;43: 184-192.

23 Aavik E, Luoto NM, Petrov L, et al: Elimination of vascular fibrointimal hyperplasia by somatostatin receptor 1.4 selective agonist. FASEB J 2002;16:724-726.

24 Du Toit D, Aavik E, Taskinen E, et al: Structure of carotid artery in baboon and rat and differences in their response to endothelial denudation angioplasty. Ann Med 2001;33: 63-78. 